\title{
УДК 159.9
}

DOI https://doi.org/10.30970/PS.2021.9.18

\section{БУЛІНГ - ЕПІДЕМІЯ СУЧАСНИХ ОСВІТНІХ ЗАКЛАДІВ}

\author{
Валерія Ладик \\ Національний педагогічний університет імені М. П. Драгоманова, \\ вул. Пирогова, 9, м. Київ, Україна, 01601 \\ e-mail: leraladick388@gmail.com
}

Явище агресії у міжособистісних стосунках здобувачів освіти $\epsilon$ найпоширенішою проблемою сучасного покоління. Через прагнення до самоствердження, жагу помсти та взаємне відчуття заздрості сучасна молодь втрачає здоровий глузд, що провокує виникнення насильства під час міжособистісного спілкування.

У сучасних освітніх закладах широко поширена проблема шкільного булінгу, яка 3 кожним роком набирає все більших обертів через звичку дорослих ії приховувати. Педагогічні працівники оберігають школу від псування власної репутації, а батьки вважають це явище звичайними дитячими пустощами. Але проблема від цього не зникає, а з кожним разом набирає все більшого масштабу, що іноді призводить до непоправних наслідків.

Мета роботи - детальне висвітлення проблеми шкільного цькування та надання практичних соціально-педагогічних та психологічних рекомендацій щодо запобігання та протидії булінгу.

За даними досліджень ЮНІСЕФ, 72\% учнів зазнавали знущань з боку своїх ровесників, серед яких $48 \%$ приховували наявність проблеми, інші $24 \%$ знайшли в собі сили розповісти про свої страждання дорослим.

Булінг - це насильницька та вкрай неприємна поведінка з боку групи дітей стосовно однієї дитини, що характеризується нерівністю сили і влади та супроводжується постійним агресивним тиском на ту ж саму дитину.

Шкільне третирування має свою структуру (агресор чи агресори, спостерігачі, жертва, іноді захисник жертви) та існує у вигляді фізичного, психологічного, матеріального, сексуального, соціального булінгу та кібербулінгу.

У ситуації булінгу може опинитися будь-хто, досить лише опинитися в ситуації нерівності прав із певною групою людей або перейти комусь дорогу.

Тривалий процес шкільного знущання призводить до непоправних наслідків як для жертви, так і для агресора. Тому своєчасне виявлення наявності проблеми в класах сучасної школи та якісне проведення профілактичної, корекційної і просвітницької роботи здатне врятувати учасників освітнього процесу від шкідливих, іноді непоправних наслідків негативної поведінки нинішніх підлітків.

Ключові слова: булінг, насильство, агресія, жага помсти, заздрість, ревнощі, боротьба за лідерство, агресор, жертва, запобігання, протидія, сучасна школа, своєчасне виявлення; профілактична, корекційна та просвітницька робота.

У середовищі підростаючого покоління все більше набирає обертів тенденція агресивності в міжособистісних стосунках: відчуття особистої неприязні, заздрість, ревнощі, жага помсти та прагнення до самоствердження переважають над здоровим глуздом у нинішньої молоді.

У сучасній школі серед учнів набула поширення проблема булінгу, яку часто прийнято замовчувати: педагоги приховують наявність знущання задля збереження репутації власної школи, а батьки вважають це явище дитячими пустощами, внаслідок чого проблема шкільного насильства не вирішується, а набуває дедалі серйозного масштабу.

(C) Ладик Валерія, 2021 
За даними дослідження, проведеного організацією ЮНІСЕФ, приблизно 72\% дітей зазнали знущань з боку своїх ровесників, серед яких $48 \%$ приховували свої страждання, інші $24 \%$ дітей знайшли в собі сили розповісти про це близьким людям.

Ця проблема до кінця не досліджена й донині, що зумовило написання цієї статті. Мета дослідження - детальне висвітлення проблеми шкільного цькування та надання практичних соціально-педагогічних і психологічних рекомендацій щодо ії запобігання та усунення.

Булінг ( з англ. bullly - хуліган, забіяка) - це агресивна, насильницька, вкрай неприємна поведінка з боку групи осіб щодо однієї особи, яка супроводжується систематичним приниженням особистості останньої.

Булінг характеризується, по-перше, нерівністю сили і влади між агресором та жертвою: булер вважає себе більш сильним та наділеним людськими правами на відміну від жертви, яка, на його думку, не має права на повагу з боку інших людей; по-друге, систематичним, повторюваним характером та спрямованістю на ту ж саму людину.

Процес шкільного знущання має таку структуру:

- агресор(и), який(i) чинить(ять) насильство;

- cпостерігачі, які є свідками негативного процесу;

- жертва - дитина, яка страждає від насильства;

- у рідкісних випадках захисник жертви, котрий намагається допомогти ображеній дитині та надати їй підтримку.

Серед спостерігачів процесу насильства існують наступні типи:

- «nасивні булери» - ті, хто активно підтримують булінг сміхом або привертанням уваги до жертви, але самі не беруть участь у цьому процесі;

- «nотенційні булери» - учні, яким подобається спостерігати за процесом знущання, але зовні вони не виявляють своєї зацікавленості в ньому;

- «байдужі свідки» - діти, які не беруть участь у процесі булінгу і вважають, що це не їхня справа;

- «потенційні захисники» - вони негативно ставляться до знущання над іншою особою, відчувають бажання допомогти їй. Але страх опинитися на місці жертви робить неможливим їхнє втручання до процесу насильства з метою захисту жертви [4].

Це і відрізняє булінг від звичайного конфлікту, який характеризується рівністю прав між його учасниками і відбувається зазвичай один або декілька разів.

Кривдникам незнайоме почуття емпатії і співчуття до інших людей, тому особа, яка потрапила до їхнього впливу, втрачає здатність чинити опір агресорам [1].

Булінг існує в таких видах:

- фізичний (побиття, штовхання, підніжки, стусани тощо);

- психологічний (образи, приниження особистості іншої людини, присвоєння образливих кличок, погрози, шантаж, залякування та інші);

- матеріальний (пошкодження та крадіжка особистих речей жертви, вимагання та відбирання у неї грошей тощо);

- сексуальний (непристойні натяки й дотики сексуального характеру, розповсюдження ганебних пліток про особисте життя жертви та опублікування в соціальних мережах іiі відвертих фото тощо);

- соціальний (жертву навмисно ігнорують, відмовляються від спілкування та співпраці $з$ нею);

- кібербулінг (вид булінгу, що здійснюється за допомогою ЗМІ: погрозливі телефонні дзвінки та СМС, розповсюдження ганебної інформації про жертву в соціальних мережах тощо) [8]. 
Серед причин виникнення явища булінгу виділяють заздрість, ревнощі, боротьба за лідерство, конкуренція, прагнення до самоствердження, жага помсти, зіткнення різних інтересів, поглядів та субкультур, відсутність організації культурного дозвілля.

Жертвою булінгу може стати будь-хто, досить лише опинитися в ситуації нерівноправності з певною групою своїх ровесників або перейти комусь дорогу. Найчастіше жертвами шкільного знущання стають:

- діми з фізичними та розумовими вадами (косоокість; заїкання; надто великий або надто малий зріст; веснянки на обличчі; незвичний колір волосся або колір шкіри, зумовлений расовою приналежністю; неохайний зовнішній вигляд; розумова відсталість або обдарованість; дуже низькі або дуже високі результати шкільного навчання);

- діти з «багатих» чи «бідних» родин;

- сором'язливі, невпевнені в собі та замкнуті учні, які бояться спілкуватися з оточуючими;

- агресивні учні, які своєю поведінкою провокують негативне ставлення до себе $з$ боку ровесників;

- конкурентоспроможні учні, які мають переваги порівняно з іншими: відмінники, талановиті та популярні діти серед значущих осіб (педагогів і представників протилежної статі) [6].

Агресорами часто стають особи, які:

- мають низьку самооцінку. Головним інструментом підняття самооцінки таких дітей $є$ не досягання життєвих успіхів, а приниження людини, яка $є$ слабшою за них. Таким чином кривдники намагаються самі собі та оточуючим довести власну суспільну значущість;

- надмірно злі та ворожі. Вони живуть за «законами джунглів», шанують культ сили, будь-який конфлікт вирішують за допомогою фізичного насильства, криків, шантажу та погроз. Для такого типу агресорів не існує загальноприйнятих правил культури поведінки в суспільстві;

- користуються підвищеним соціальним статусом серед однолітків та мають завищену самооцінку. Тип агресорів, який має високий рівень самовпевненості, користується популярністю серед ровесників та не має сумнівів із приводу правильності своєї поведінки. Найчастіше так себе поводять підлітки, у сім'ях яких панує культ вседозволеності;

- самі пережили насильство (в іншій школі або вдома). Дуже часто діти, які в минулому страждали від знущання, переносять свою агресію на більш слабких учнів через невміння адекватним чином долати власні негативні емоції [5].

Процес тривалого знущання має згубні наслідки для жертви:

- nсихічні розлади. Психіка людини, яка в минулому пережила насильство, має ознаки тривожності та невпевненості в собі. У колишньої жертви постійно існує потреба в моральній підтримці та підбадьорюванні з боку оточуючих;

- складнощі у встановленні контактів та підтримуванні міжособистісних взасмин. У колишньої жертви шкільного булінгу існують дуже великі шанси опинитися в ролі жертви мобінгу на робочому місці. Таким людям важко знайти спільну мову зі своїми колегами та керівництвом. Жертву часто цькують співробітники з метою іï подальшого звільнення. Нерідко вона стикається з труднощами у взаєминах з представниками протилежної статі;

- психосоматичні хвороби. У людини, яка пережила шкільний боулінг, спостерігаються такі симптоми, як порушення апетиту (його втрата або підвищення), анорексія, булімія, часте безсоння (інсомнія), часті простудні та інфекційні захворювання; 
- суїцидальні наміри. Через постійні страждання від тривалого насильства в жертви виникає відчуття власної непотрібності та відторгнення, внаслідок чого може виникнути бажання звести рахунки зі своїм життям (особливо це відбувається у випадках, коли, крім страждань від булінгу, жертва стикається з відмовою батьків надати їй допомогу). Батьки вважають це явище звичайною дитячою забавою та знецінюють страждання жертви.

Під час здійснення насильства над іншою людиною булери страждають менше жертви через відсутність емпатії, але їх надалі також не оминають наслідки шкільного боулінгу, а саме:

- неблагополучне майбутнє. Потрапляючи у простір дорослого життя, дитячі асоціальні риси поведінки зникають, і колишні булери опиняються на смітнику життя. Вони не досягають життєвих успіхів, тоді як їхні колишні жертви закінчують університети та влаштовуються на престижну високооплачувану роботу. Агресор може опинитися в тюремній камері або ж мати низько кваліфіковану й низькооплачувану роботу;

- терор у сім'ї та в робочому колективі. Колишні булери не вміють встановлювати теплих довірливих стосунків з оточуючими: часто вони стають аб'юзерами щодо своїх партнерів і дітей. У робочому колективі їх намагаються уникати колеги, оскільки колишнім агресорам властиві риси диктаторів, пліткарів, інтриганів. Вони пліткують про успішних колег, ставлять їм «палки в колеса», підсиджують на роботі, йдуть до своєї мети «по головах», внаслідок чого наживають собі ворогів [7].

Загальними соціально-педагогічними та психологічними рекомендаціями щцоо запобігання явища булінгу для педагогів є такі: дітей;

1) уважний контроль за поведінкою та особливостями міжособистісних стосунків

2) відмовляння від прилюдних зауважень стосовно певних учнів та застосування суджень без оцінки; сприяння припиненню будь-яких проявів глузування, насмішок та не толерантного взаємного ставлення. Спільно з учнями розроблення правил поведінки у класі та слідкування за їх дотриманням;

3) регулярне проведення практичним психологом та соціальним педагогом анкетування, спрямованого на виявлення учнів, схильних до скоєння насильства, та потенційних жертв булінгу. Згідно з результатами тестувань планування та проведення з дітьми, батьками й педагогами профілактичної, корекційно-розвивальної і просвітницької роботи з питань запобігання та протидії булінгу, використовуючи зокрема психологічний та соціально-педагогічний інструментарій (матеріали для проведення класних годин, тренінгові програми, інші технології психологічного й соціально-педагогічного впливу на учасників освітнього процесу);

4) педагоги мають здійснювати роботу з художніми творами, в яких відображено проблему цькування (під час читання учні співпереживають із героями та порівнюють себе з ними); організувати перегляд фільму «Опудало» за повістю Ст. Железнякова (автор написав повість на основі випадку, який стався з його внучкою), а також написання учнями творів, есе на тему цькування, коли вони мають можливість висловити власну думку з приводу цього явища та відчути проблему;

5) батьки повинні володіти навичками вчасного виявлення ознак того, що їхня дитина стала жертвою булінгу, та надати їй якісну допомогу й підтримку [2].

Соціально-педагогічні та психологічні рекомендації педагогам та батькам 3 приводу роботи з учнем, який став жертвою икільного булінгу:

1) пам'ятайте: діти, які стали жертвами булінгу, часто соромляться повідомляти про свою проблему дорослим, адже їм здається, що проблема в них самих і що вони заслуговують на таке ставлення. Дитині неприємно говорити на цю тему, оскільки жертви булінгу дуже вразливі; 
2) починайте розмову тільки після того, як заспокоїтесь;

3) дайте зрозуміти дитині, що ви завжди на їі боці, готові зрозуміти і1і, надати допомогу та не звинувачуєте дитину в тому, що сталося;

4) запевніть дитину в тому, що вона правильно вчинила, розповівши вам про наявність проблеми булінгу, оскільки існує велика різниця між доносом та піклуванням про власне благополуччя;

5) спільно з дитиною обговорюйте варіанти рішення проблеми шкільного насильства (звернення до шкільного психолога, педагогів, класного керівника, батьків, дорослих учнів, ювенальної превенції школи та служби у справах неповнолітніх дітей), поцікавтеся у дитини, яка ваша допомога буде їй корисною;

6) підтримуйте дитину в налагодженні дружніх стосунків із однокласниками та дайте їй зрозуміти, що зміни відбуватимуться поступово і що вона може розраховувати на вашу підтримку.

Соціально-педагогічні та психологічні рекомендації педагогам та батькам щцодо роботи з учнем-агресором:

1) 3'ясуйте в дитини мотиви своїх дій, іiї ставлення до них, як на це реагують інші діти;

2) не зменшуйте серйозність ситуації стереотипними кліше: «агресія, бійки та приниження є звичайною дитячою забавою, яка з віком пройде»;

3) поясніть агресору, що такі дії, як висміювання, погрози, приниження, штовхання, побиття та бойкот, $є$ насильством, яке іноді призводить до непоправних наслідків;

4) чітко дайте зрозуміти кривднику, що ви не будете миритися з його поведінкою, суворо вимагаєте припинити булінг і слідкуєте за поведінкою дитини задля того, щоб впевнитись у прагненні кривдника змінити власну поведінку;

5) покарання та загрози можуть лише на певний час припинити цькування, але в подальшій перспективі агресія щодо слабшого може посилитися через жагу помсти;

6) той, хто скоює знущання, зазвичай позбавлений емпатії, тому акцентувати його увагу на почуттях жертви насильства не має сенсу;

7) пам'ятайте, що дитина, яка скоює насильство щодо інших, має проблеми в емоційній та поведінковій сфері, отже потребує допомоги. В такому випадку класний керівник та батьки булера повинні постійно спілкуватися між собою заради допомоги дитині [3].

Отже, проблема шкільного насильства $є$ однією з найпоширеніших проблем у сучасному освітньому середовищі.

За даними дослідження, проведеного організацією ЮНІСЕФ, 72\% дітей страждали від булінгу, 48\% з них приховували наявність цієї проблеми, а 24\% вирішили розповісти про це близьким людям.

Булінг ( з англ. bullly - хуліган, забіяка) - це агресивна, насильницька і вкрай неприємна поведінка з боку групи осіб щодо однієї особи, яка супроводжується систематичним приниженням особистості останньої.

Шкільний булінг відрізняється від звичайного конфлікту дисбалансом сили і влади та наявністю відповідної структури: агресор(и), спостерігачі, жертва, іноді захисник жертви. Існують такі види боулінгу: фізичний, психологічний, матеріальний, сексуальний, соціальний булінг та кібербулінг.

Серед причин боулінгу виділяють заздрість, ревнощі, жага помсти, боротьба за лідерство. Жертвою шкільного насильства може стати будь-хто, досить лише опинитися в ситуації нерівноправності з певним колом учнів або перейти комусь дорогу. Але найчастіше жертвами булінгу стають учні, які мають фізичні та розумові вади, сором'язливі, невпевнені в собі або, навпаки, агресивні. 
Тривалий процес шкільного знущання має згубні наслідки як для жертви (проблеми у взаєминах у майбутньому, занижена самооцінка, тривожність, психосоматичні захворювання і навіть суїцидальні наміри), так і для булера (кримінальне та малозабезпечене майбутнє, проблеми у взаєминах з колегами та сім'єю).

Для того, щоб запобігти та протидіяти явищу шкільного насильства, потрібно вміти вчасно виявляти його ознаки та застосовувати профілактичну, корекційно-розвивальну та просвітницьку роботу з учнями, батьками та педагогами.

Пам'ятайте: діти, які скоюють насильство, і ті діти, які від нього страждають, потребують Вашої допомоги!

\title{
Список використаної літератури
}

1. Брочковська Ю.Б. Буллінг як соціально-психологічна проблема. Науковий вісник Львівського державного університету внутрішніх справ. 2011. Вип. 2. С. 28-34.

2. Клименко Ю.О., Сайко Н.О., Шевчук В.В. Соціально-психологічна профілактика булінгу в освітньому середовищі. Science and Education a New Dimension. Pedagogy and Psychology. VI (75). Issue: 181. 2018.

3. Кон И.С. Что такое буллинг и как с ним бороться? [Электронный ресурс].

4. Лушпай Л.І.Шкільний булінг як різновид суспільноїагресії[Електронний ресурс]. Наук. зап. [Наи. ун-ту «Острозька академія»]. Сер.: Фізіологічна. 2013. Вип. 33. С. 56-67.

5. Лэйн Д.А. Школьная травля (буллинг) [Электронный pecypc]. ZipSites. ru : бесплат. електрон. интернет б-ка. Режим доступа : http://www.zipsites.ru/psy/psyib/ info.php? $=414$.

6. Насильство. Булінг. Проблема в запитаннях та відповідях [Текст]. I.I. Дорожко, О.С. Малихіна, Л.В. Туріщева. Харків : ВГ «Основа», 2019.

7. Стельмах С. Булінг у школі та його наслідки. Гуманізація навчально-виховного процесу: збірник наукових праць. [За заг. ред. проф. В.I. Сипченка]. - Вип LVI. Слов’янськ: СДПУ, 2011. 123 с.

8. Попередження, виявлення і подолання випадків насильства та жорстокого поводження з дітьми : методичний посібник для освітян. Авт.: Журавель Т. В., Кочемировська О. О., Ясеновська М.Е. За заг. ред. Безпалько О.В. Київ : ТОВ «К.І.С.», 2010. 234 с.

\section{BULLYING - AN EPIDEMIC OF MODERN EDUCATIONAL INSTITUTIONS}

\author{
Valeria Ladyk \\ National Pedagogical Dragomanov University, \\ 9, Pirogova str., Kyiv, Ukraine, 01601 \\ e-mail:leraladick388@gmail.com
}

The phenomenon of aggression in interpersonal relationships of students is the most common problem of the modern generation. Due to the desire for self-affirmation, thirst for revenge and envy of each other, modern youth lose their sanity, which provokes violence in their interpersonal communication.

The problem of school bullying is widespread in modern educational institutions, which is gaining momentum every year due to the habit of adults to hide it. Teachers protect the school from damaging their own reputation, and parents consider this phenomenon a common childish prank. But the problem does not disappear from this, and each time gaining more and more scale, which sometimes leads to irreparable consequences.

The purpose of the article: detailed coverage of the problem of school bullying and providing practical socio-pedagogical and psychological recommendations to prevent

According to a UNICEF study, $72 \%$ of students were bullied by their peers, of whom $48 \%$ hid the problem from prying eyes and another $24 \%$ found the strength to tell adults about their suffering. 
Bullying is a violent and extremely unpleasant behavior on the part of a group of children towards one child, which is characterized by inequality of power and authority and is accompanied by constant aggressive pressure on the same child.

School treatment has the following structure: aggressor (s), observers, victim and, in rare cases, defender of the victim and exists in the following types: physical, psychological, material, sexual, social and cyberbullying.

Anyone can find themselves in a bullying situation. All you have to do is find yourself in a situation of inequality of rights with a certain group of people or cross someone's path.

The long process of school bullying leads to irreparable consequences for both the victim and the aggressor. Therefore, timely detection of the problem in the classrooms of a modern school and high-quality preventive, corrective and educational work can save participants in the educational process from harmful and sometimes irreparable consequences of negative behavior of today's adolescents.

Key words: bullying, violence, aggression, thirst for revenge, envy, jealousy, struggle for leadership, aggressor, victim, prevention, counteraction, modern school, timely detection, preventive, corrective and educational work. 